\title{
Notes on the Fundamental Unity of Humankind
}

\author{
Wim van Binsbergen \\ African Studies Centre, Leiden University, Leiden, the Netherlands \\ wimvanbinsbergen@gmail.com
}

\begin{abstract}
The argument claims the vital importance of the idea of the fundamental unity of humankind for any intercultural philosophy, and succinctly traces the trajectory of this idea - and its denials - in the Western and the African traditions of philosophical and empirical research. The conclusion considers the present-day challenges towards this idea's implementation - timely as it is, yet apparently impotent in the face of mounting global violence.
\end{abstract}

\section{Keywords}

fundamental unity of humankind - intercultural philosophy - history of Western thought - African philosophy - history of the social sciences - violence

Despite $^{1}$ its impressive achievements and, by now, respectable age, African Philosophy has so far had remarkably little impact on mainstream cosmopolitan philosophy. Beyond the names of V.Y. Mudimbe and Kwame Anthony Appiah, few cosmopolitan philosophers would be familiar with even the major exponents and debates that, over the last seventy years, have made African Philosophy one of the most exciting provinces of modern thought. The exchange of ideas has remained remarkably one-sided. Inevitably,

1 This is a considerably revised version of an argument that restates and develops a position set out in the beginning of my book Vicarious Reflections. Wim M.J. van Binsbergen, Vicarious Reflections: African Explorations in Empirically-grounded Intercultural Philosophy, Papers in Intercultural Philosophy and Transcontinental Comparative Studies, No. 17 (Haarlem: PIP-TraCS, 2016). Also at: http://www.quest-journal.net/shikanda/topicalities/vicarious/ vicariou.htm. 
transcontinental influences and tendencies have had their impact on African Philosophy. ${ }^{2}$ But African philosopher Kwasi Wiredu has been one of the few contemporary thinkers to pioneer the vital issue of cultural universals - a fact that has gone largely unnoticed by those who a few decades ago were climbing, ${ }^{3}$ and by now are falling off, the fashionable band wagons of poststructuralism to mimic Michel Foucault and Gilles Deleuze in an alarming fixation on the North Atlantic urban experience of (post)modernity.

I occasionally pick up wind-blown sounds of a distant carnival procession I was too late to join. During the larger part of my academic career I identified myself as a mainstream Africanist, anthropologist of religion, professor and research administrator. But prolonged and intensive engagement with African social, cultural and religious life typically through anthropological fieldwork brought me in the course of the 199os to question the subordinating nature of North-South knowledge formation. I began to look for alternatives in Afrocentrism and the Black Athena thesis by Martin Gardiner Bernal, to whose debates I contributed extensively. This preoccupation led to a number of publications, which allowed me in 1998 to trade my Amsterdam (Free University) chair in the Social Anthropology of Ethnicity for one in the Foundations of Intercultural Philosophy within the Philosophical Faculty of Erasmus University Rotterdam. In the process, the editorship of Quest: An African Journal of Philosophy / Revue Africaine de Philosophy was entrusted to me. Still most at home in essentially illiterate rural situations (as an ethnographic and oral-historical field-worker with a handful of African and Mediterranean cultures and languages more or less at my fingertips), I was keen to trace the history and the varieties of human thought beyond the frozen texts out of which most mainstream philosophy is distilled and into regions and periods where few of my new philosophical colleagues would be able to follow me, where still fewer would be able to survive and function, and where hardly one of them would perceive any philosophy to speak of. I implicitly based my attempts at intercultural philosophy not only on my descriptive and theoretical experience

2 E.g. Wim M.J. van Binsbergen, ed., Lines and Rhizomes: The Transcontinental Element in African Philosophies, special issue of Quest: An African Journal of Philosophy/Revue Africaine de Philosophie, vol. xxI (2007); or as far as the feminist turn is concerned, Sanya Osha, with the assistance of Wim M.J. van Binsbergen, ed., African Feminisms, special issue of: Quest: An African Journal of Philosophy/Revue Africaine de Philosophie, Vol. xx, No. 1-2 (2006). Full text at http://www.quest-journal.net/2oo6.htm.

3 See Kwasi Wiredu, "Are There Cultural Universals?," Quest: Philosophical Discussions 4, 2 (1990): 4-19; Kwasi Wiredu, Cultural Universals and Particulars: An African Perspective (Bloomington \& Indianapolis: Indiana University Press, 1996). 
in anthropology and sociology but also on the postulate of "the fundamental unity of humankind" (at least, of Anatomically Modern Humans - the subspecies that emerged in East Africa c. $200 \mathrm{ka} \mathrm{BP},{ }^{4}$ and to which all humans now living belong). I misguidedly expected from further transcontinental empirical research the firm substantiation of that postulate without realising that on this point (as on many others) philosophers, however naïve in their approach to empirical data, had already thought far ahead of social scientists in many respects. I began to realise that any contribution I was to make to intercultural philosophy would require that I develop an argument on the fundamental unity of humankind - thus defining a context, a space, for such interculturality as might be precariously possible in theory and practice.

Rather more narrowly than encompassing the full extent of humanity, the fundamental unity of African peoples and civilisations has been passionately affirmed, ${ }^{5}$ and denied. ${ }^{6}$ Similar claims of fundamental unity have been made in mainstream anthropology for every major culture province, e.g. the

$4 \mathrm{ka}=$ kiloyear, millennium, 1,ooo years; BP = Before Present.

5 See Anta Cheikh Diop, Cheikh Anta, L'Unité culturelle de l'Afrique noire (Paris: Présence Africaine, 1959), English tr. The Cultural Unity of Black Africa: The Domains of Patriarchy and of Matriarchy in Classical Antiquity (London: Karnak House, 1989). See also Felix Chami, The Unity of the African Ancient History: 3000 BC to AD 500 (Mauritius: E \& D, 2006); Jacques Jerôme Maquet, Africanité traditionelle et moderne (Paris: Présence Africaine, 1967), trans. in English by Joan R. Rayfield as Africanity: The Cultural Unity of Black Africa (London: Oxford University Press, 1975); Michael Rowlands, "The unity of Africa," in David O'Connor and Andrew Reid, Ancient Egypt in Africa (London: UCL Press, 2003), 39-54. For the Afrocentrist Clyde A. Winters, this "unity" even extends to include South Asian speakers of the Dravidian linguistic phylum, and groups in East and South East Asia; see Clyde A. Winters, "The Genetic Unity of Dravidian and African Languages and Culture," in Proceedings of the International Symposium on Asian Studies (PISAS) 1979 (Hong Kong: Asian Research Service, 1980) (non vidi, only available in Web summary); and "A Note on the Unity of Black Civilizations in Africa, Indo-China, and China," in Proceedings of the International Symposium on Asian Studies (PISAS) (Hong Kong: Asian Research Service, 1980) (non vidi, only available in Web summary).

6 See Didier N. Kaphagawani and Jeanette G. Malherbe, "African epistemology," in P.H. Coetzee, and A.P.J. Roux, eds, The African Philosophy Reader (London: Routledge, 1998), 205-216; Kwame Anthony Appiah, In my Father's House: Africa in the Philosophy of Culture (New York \& London: Oxford University Press, 1992); Stephen Howe, Afrocentrism: Mythical Pasts and Imagined homes (London \& New York: Verso, 1998) and François-Xavier Fauvelle, L'Afrique de Cheikh Anta Diop (Paris: Karthala, 1996) as devastating critics of Afrocentricity; see also van Binsbergen, Vicarious Reflections, Ch. 12, on Mudimbe. 
Mediterranean, ${ }^{7}$ Indonesia, ${ }^{8}$ the Ancient Near East, ${ }^{9}$ the Slavonic world, ${ }^{10}$ the world of Islam, ${ }^{11}$ and Western civilisation. ${ }^{12}$ On the basis of considerations that led to the Whorf-Sapir thesis concerning the over-determination of thought and life world by language, ${ }^{13}$ it has been particularly tempting (but often also unmistakably ideological and political) to claim the unity of large population groups because they turned out to be speaking branches of the same linguistic family, phylum or even macrophylum. This claim has been made regarding the Indo-European, ${ }^{14}$ Austronesian, and the Bantu family of languages in particular.

7 See David G. Gilmore, ed., Honor and Shame and the Unity of the Mediterranean (Washington DC: American Anthropological Association, 1987).

8 See P.E. de Josselin de Jong, ed., Unity in Diversity: Indonesia as a Field of Anthropological Study, Verhandelingen van het Koninklijk Instituut voor Taal-, Land- en Volkenkunde, 103 (Dordrecht \& Cinnaminson: Foris, 1984).

9 See Hans Goedicke and J.J.M. Roberts, eds, Unity and Diversity: Essays in the History, Literature, and Religion of the Ancient Near East, Johns Hopkins Near Eastern Studies (Baltimore:Johns Hopkins University Press, 1975); Henri Frankfort, Kingship and the Gods: A Study of Ancient Near Eastern Religion as the Integration of Society and Nature (Chicago: University of Chicago Press, 1948); The Birth of Civilization in the Near East (Bloomington: Indiana University Press, 1951); The Problem of Similarity in Ancient Near Eastern Religions, Frazer Lecture 1950 (Oxford: Clarendon Press, 1951).

10 See D. Madunišs, "Vinko Pribojevic and the Glory of Slavs," Magisterská práce, [MA thesis], Historický ústav Stredoevropské univerzity Budapešt (2003); F.J. Los, Oost-Europa: In vóóren vroeghistorische tijd (Oostburg: Pieters, 1969).

11 See Clifford Geertz, Islam Observed:Religious Development in Morocco and Indonesia (New Haven \& London: Yale University Press, 1968); Marshall Hodgson, The Venture of Islam: Conscience and History in World Civilization, I-III (Chicago: University of Chicago Press, 1974); Lewis 1976, 1993. Bernard Lewis, The World of Islam: Faith, People, Culture (London: Thames \& Hudson, 1976); The Arabs in History (London: Oxford University Press, 1993).

12 Francis Sydney Marvin, The Unity of Western Civilization: Essays (London: Milford, 1915).

13 See Benjamin Lee Whorf, Language, Thought, and Reality (New York \& London: MIT Press, 1956); Edward Sapir, Selected Writings in Language, Culture and Personality, ed. David Goodman Mandelbaum (Berkeley: University of California Press, 1929/49); van Binsbergen, Vicarious Reflections, ch. 6, footnote 242, with further literature.

14 It is difficult to be consistent in the rendering of the names of linguistic macrophyla. In general, I have followed the usage of state-of-the-art long-range linguistics as represented in the global Tower of Babel project (Starostin \& Starostin 1998-2008), so while aware of the disparate nature of the underlying constituent languages or regions, I am writing "Afroasiatic," "Khoisan," "Sinocaucasian," etc., instead of Afro-Asiatic, Khoi-San or Sino-Caucasian; but with the exception of Indo-European, where I have inserted a hyphen and a capital letter, not for Eurocentric hegemonic reasons but in order to keep this composite word transparent and pronounceable. 
Speculations on humankind's original language go back to classical Antiquity ${ }^{15}$ and suggest an underlying assumption of the monogenesis of human speech in accordance with the Israelite claim made at roughly the same time in Genesis 11:1. Although in Genesis 10:5, 20, and 31, a plurality of tongues is acknowledged. In the nineteenth century $\mathrm{CE}$, when linguistic theory was reaching considerable levels of sophistication and comparison, similar ideas were formulated again, for the whole of humankind, by Johnes. ${ }^{16}$

Despite all these claims of the unity of subsets of humanity, the unity of humankind as a whole has comparatively rarely been subject of empirical scientific debate. Research and theory in the human sciences, including physical and cultural anthropology and the study of ethnicity, have concentrated on differences, not convergence or unity. The nineteenth century CE was the century that saw the rise of the sciences of Man, but also the rise of quasiscientific racism, ${ }^{17}$ and polygeny rather than monogeny better fit that regrettable paradigm. Yet one of the greatest pioneers of the idea of prehistory, Armand de Quatrefages, wrote his Unité de l'espèce humaine at an early stage (1861). But by and large, until recently, the very idea of universals of human

15 Notably the cruel experiment - raising newborn infants in total isolation so as to determine the specific language of the first word they would utter - conducted by the Late-Period Egyptian king Psammetihus / Psamtik as reported by Herodotos, Historiae II, 2 and 15; the first utterance happened to sound like "bread" in the Indo-European language Phrygian. By an amusing coincidence of history or of scholarship (if it was just that; Bedřich Hrozný must have known his Herodotus) it was also a word for "bread" again, in: $n u$ [nind a SUMERogram ] an e-iz-za-at-te-ni "now PANEM you eat" wa-a-tar-ma e-ku-ut-te-ni "water then you drink"

in Cyrus H. Gordon, Forgotten Scripts: Their Ongoing Discovery and Decipherment (New York: Basic Books, 1982), 93; originally Forgotten Scripts: The Story of their Decipherment (London: Penguin, 1975); also reprinted in 1987 (New York: Dorset); C.W. Ceram, Smal ravijn en zwarte berg: Het geheim van het Hetietenrijk (Amsterdam \& Antwerpen: Van Ditmar, 1955), 77 [Dutch translation of Enge Schlucht und schwarzer Berg (Hamburg: Rowohlt, 1955)]. They offered Hrozný the clue to the decipherment of the cuneiform version of the Hittites' language, whose ancient empire extended westward to include Phrygia!

16 See Arthur James Johnes, Philological Proofs of the Original Unity and Recent Origin of the Human Race, Derived from a Comparison of the Languages of Asia, Europe, Africa, and America: Being an inquiry how far the differences in the languages of the globe are referrible to causes now in operation (London: Smith, 1846); see also Frédéric Guillaume Bergmann, Résumé d'études d'ontologie générale et de linguistique générale, ou: Essais sur la nature et l'origine des êtres, la pluralité des langues primitives, et la formation de la matière première des mots (Paris: Cherbuliez, 1869); James H. Stam, Inquiries into the Origins of Language: The Fate of a Question (New York: Harper \& Row, 1976).

17 E.g. Joseph-Arthur de Gobineau, Essai sur l'inégalité des races humaines, I-IV (Paris: Firmin-Didot, 1853). 
culture or language has been abhorred. ${ }^{18}$ The contemplation of especially the somatic diversity of humans, usually under the heading of "race,"19 used to dominate handbooks of physical anthropology, and the question as to what humans have in common seldom came up. Even such a great anthropologist as Alfred Kroeber prided himself to have designed a new, even finer classification of races in what he considered his major work (1923 etc.). An exception were the writings of the Humanistic School of American anthropology, with such authors as Margaret Mead and especially Clyde Kluckhohn with Mirror for Man ${ }^{20}$ and Common Humanity and Diverse Cultures. ${ }^{21} \mathrm{~A}$ handful of other scholarly titles specifically addressing the unity of humankind focus on the much-researched topic of the origin of the populations of the Americas. ${ }^{22}$ In the first half of the twentieth century CE, leading American anthropologists predominantly Americanists - tended to oppose diffusion for much the same reason that present-day Africanists dislike the idea: diffusion implies that the African cultures they claim to cherish professionally ${ }^{23}$ have always been part of the wider intercontinental world and therefore, just like European cultures (and despite the historically understandable tendency towards the vicarious

18 Obviously, the issue of the fundamental unity of humankind is closely related to that of universals of culture and of language, such universals being the very hallmark of the proclaimed unity. In my recent work, I have repeatedly returned to this question, e.g. Wim M.J. van Binsbergen, Confronting the Sacred: Durkheim Vindicated through Philosophical Analysis, Ethnography, Archaeology, Long-range Linguistics, and Comparative Mythology (Hoofddorp: Shikanda Press, 2018), section 9.2, 331 f; also at http://www.quest -journal.net/shikanda/topicalities/naar\%2owebsite\%208-2018/Table_of_contents.htm.

19 Which was only discarded after the tragedies associated with that concept during World War II; see Ashley Montagu, Man's Most Dangerous Myth: The Fallacy of Race, 5 th edition (New York: Columbia University Press, 1974 [first published 1942, reprinted 1945]); Claude Lévi-Strauss, Race and History (Paris: Unesco, 1952); Léon Poliakov, De arische mythe: Over de bronnen van het racisme en de verschillende vormen van nationalisme, Amsterdam: Arbeiderspers; Dutch tr. of Le mythe aryen (Paris: Calmann-Lévy, 1979 [1971]).

20 See Clyde Kluckhohn, Mirror for Man (New York: McGraw-Hill, 1949).

21 See Clyde Kluckhohn, Common Humanity and diverse Cultures: The Human Meaning of the Social Sciences, ed. Daniel Lerner (New York: Meridian, 1959).

22 J. Walter Fewkes, "The Problems of the Unity or Plurality and the Probable Place of Origin of the American Aborigines." American Anthropologist 14, 1 (1912): 1-59.

23 See Wim M.J. van Binsbergen, "Rethinking Africa's transcontinental continuities in preand protohistory," keynote paper presented at the Rethinking Africa's transcontinental continuities in pre- and protohistory International Conference, African Studies Centre, Leiden, 12-13 April 2012: http://www.shikanda.net/Rethinking_history_conference/ wim_keynote.pdf; final publication in Wim M.J. van Binsbergen, ed., Rethinking Africa's Transcontinental Continuities: Proceedings of the Leiden 2012 International Conference, special issue, Quest: An African Journal of Philosophy / Revue Africaine de Philosophie, vols 26-28 (2019): 55-96. 
and pathetic essentialisation of things African), they may be legitimately considered from a point of view of transcontinental continuities. One example from among many of the American stance is Leslie Spier who, when positively reviewing Roland B. Dixon's The Building of Cultures (1928), dextrously applied the point of "psychic unity" as a negative argument for diffusion of geographically similar traits:

The environmental discussion is but a preface to one of discovery and invention, which turns ultimately on the question of culture parallels. The factors that make novelties possible are opportunity, need, and genius, each a variable, hence in combination kaleidoscopic in results. Yet the more general the opportunity, the more widespread the need, and the lower the genius required, the greater the possibility of approximate duplications hither and yon. What the extreme diffusionists will not see is that the "psychic unity" necessary for culture parallels is little more than the most generalized forms of these three factors. ${ }^{24}$

Reconsidering the same question four decades later, James A. Ford broadens it from a continental to a world-wide focus, ${ }^{25}$ and does so from the perspective of the well-known controversy between (a) cultural diffusion of region-specific culture traits, versus (b) the thesis that explains the similarities between geographically remote culture traits on the basis of "the fundamental unity of the human mind" (a point also made in more recent decades by Jürgen Habermas), ${ }^{26}$ conceivably resulting in independent yet converging inventions at different parts of the globe.

The topic of the fundamental unity of humanity has invited not only wild speculation along theosophical and New-Age lines; but also more scientifically informed extrapolation. Remarkably, humankind's unity was a focal point in Adolf Bastians's (1826-1905) contributions to German protoanthropology. ${ }^{27}$ Among the early, proclaimedly scientific, explorations of the

\footnotetext{
24 See Leslie Spier, "Review of Roland B. Dixon, The Building of Cultures, 1929," American Anthropologist, 31, 1 (Jan.-Mar. 1929): 140-145.

25 See James A. Ford, A Comparison of Formative Cultures in the Americas: Diffusion or the Psychic Unity of Man, Smithsonian Contributions to Anthropology (Washington DC: Smithsonian Institution Press, 1969).

26 Jürgen Habermas, "Die Einheit der Vernunft in der Vielheit ihrer Stimmen," Merkur, 42, 467 (1988): 1-14.

27 Adolf Bastian, Das Beständige in den Menschenrassen und die Spielweite ihrer Veränderlichkeit. Prolegomena zu einer Ethnologie der Culturvölker (Berlin: Reimer, 1868).
} 
unity of humankind we may also mention John Bachman. ${ }^{28}$ Another early example is the consideration of the possibility of extraterrestrial life by Charles Darwin's counterpart in the discovery of evolution, Alfred Russel Wallace - but the unity of humankind implied by the latter is merely one by negation: nonextraterrestrial. ${ }^{29}$ Similar boundary explorations are offered in the growing literature on interspecies relationships and animal rights, but again they tend to offer an image of unity by negation, not by substance (e.g. Donald Turner, with extensive references). ${ }^{30}$ The palaeontologist Pierre Teilhard de Chardin, too, started out from personal natural-science competence but worked towards a cosmic vision of the unity and uniqueness of humankind ${ }^{31}$ as forming a noösphere on the way to convergence with the divine - almost a poor man's and hear-say version of Georg Wilhelm Friedrich Hegel's view of history. ${ }^{32}$ In palaeoanthropology the monogenetic versus polygenetic origin of humans (and of language $)^{33}$ has constituted the subject for passionate debate at least since Darwin. ${ }^{34}$ While this debate still goes on regarding the earliest genesis of Man some three or four million years BP, present-day physical anthropology has

28 John Bachman, The Doctrine of the Unity of the Human Race Examined on the Principles of Science (Charleston: Canning, 1850).

29 Alfred Russel Wallace, Man's Place in the Universe: A Study of the Results of Scientific Research in Relation to the Unity or Plurality of Worlds (London: Chapman \& Hall, 1904).

30 Donald Turner, "Altruism across Species Boundaries: Kant and Levinas on the Meaning of Human Uniqueness," n.d., at http://www.metanexus.net/conference2oo3/pdf/WOL Paper_Turner_Donald.pdf.

31 See PierreTeilhard de Chardin, Les oeuvres complètes, I. Le phénomène humain (Paris: Seuil, 1955); Les oeuvres complètes, II. L'Apparition de l'homme (Paris: Seuil, 1956); Les oeuvres complètes, VIII. La place de l'homme dans la nature (Le groupe zoologique humaine) (Paris: Seuil, 1965 [first published Paris: Albin Michel, 1956]). That his scientific competence was acquired relatively late in life (in accordance with the typical Jesuit career) is clear from his blundering (if not more guilty role) in the Piltdown forgery case. But despite his unitary vision of the origins of humanity, his palaeoanthropological work led him to suggest "la probabilité d'une bifurcation précoce" in the earliest phase of humankind, close to its place of origin - a primordial split allegedly separating once and for all the putative African and Asian branches (see Teilhard de Chardin, L'Apparition de l'homme, 257-261). Half a century later we still find the (then, in the pre-molecular-biology phase) leading geneticist Luigi Cavalli-Sforza toying with the same idea of a fundamental split, see Fig. 1. See G.W.F. Hegel, Die Phänomenologie des Geistes (first published Bamberg and Wür(t) zburg, 1807); English translation A.V. Miller, The Phenomenology of Spirit (Oxford: Clarendon Press, 1977).

33 See Alfredo Trombetti, Come si fa la critica di un libro: Con nuovi contributi alla dottrina della monogenesi del linguaggio e alla glottologia generale comparata (Bologna: Beltrami, 1907).

34 See Charles Darwin, The Descent of Man, and Selection in Relation to Sex (London: Murray, 1871). 
largely accepted the fundamental unity of the much more recent Anatomically Modern Humans (emerging in East Africa only c. 200 ka BP) on overwhelming anatomical and genetic grounds - to which work on human universals, ${ }^{35}$ linguistics, ${ }^{36}$ comparative mythology, ${ }^{37}$ and comparative religion notably in regard to shamanism, ${ }^{38}$ has added impressive socio-cultural arguments. Even a century ago the comparative study of humankind's major symbols ${ }^{39}$ and religious forms ${ }^{40}$ had led to similar suggestions, but on empirically, methodologically and theoretically far less convincing grounds. Of course, the entire fields of physical anthropology, medical anthropology, the anthropology of sexuality and the anthropology of death, are predicated on the fact that humans, and especially the Anatomically Modern Humans of the last $200 \mathrm{Ma}$, all share (female and male versions of) essentially the same body, and thus have converging experiences of bodily functions, birth, growth, illness and death. Many anthropologists have noticed that in fieldwork especially participating in such body-induced experiences - notably in illness and death - tends to induce instances of transcultural communality between the research hosts and the researcher, even if the latter's linguistic and cultural local competence is still minimal. Yet as a potentially central concern in the social sciences, and one of

35 See Wiredu, "Are There Cultural Universals?" and Cultural Universals and Particulars; Donald E. Brown, Human Universals (New York: McGraw-Hill, 1991).

36 See John D. Bengtson and Merritt Ruhlen, "Global Etymologies," in Merritt Ruhlen, ed., On the Origins of Languages: Studies in Linguistic Taxonomy (Stanford: Stanford University Press, 1994); Sergei Starostin and George Starostin Starostin, Tower of Babel etymological database, participants: Russian State University of the Humanities (Center of Comparative Linguistics), Moscow Jewish University, Russian Academy of Sciences (Dept. of History and Philology), Santa Fe Institute (New Mexico, USA), City University of Hong Kong, and Leiden University, 1998-2008. At: http://starling.rinet.ru/babel.htm.

37 See Michael Witzel, The Origins of the World's Mythologies (New York: Oxford University Press, 2012); Wim M.J. van Binsbergen and Eric Venbrux, eds, New Perspectives on Myth: Proceedings of the Second Annual Conference of the International Association for Comparative Mythology (Haarlem: Papers in Intercultural Philosophy and Transcontinental Comparative Studies, 2010). Also at: http://www.quest-journal.net/PIP/ New_Perspectives_On_Myth_2010/toc_proceedings_IACM_2008_2010.htm.

38 See Mircea Eliade, Le chamanisme et les techniques archaïques de l'extase (Paris: Payot, 1951). Translated in English as Shamanism: Archaic Techniques of Ecstasy (New York: Bollingen, 1968); Andreas Lommel, Shamanism (New York: McGraw-Hill, 1967).

39 See Elisabeth E. Goldsmith, Life Symbols as Related to Sex Symbolism (New York: Putnam, 1924); Detlef Ingo Lauf, Symbole: Verschiedenheit und Einheit in östlicher und westlicher Kultur (Frankfurt am Main: Insel, 1976).

40 See William Williamson, The Great Law: A Study of Religious Origins and of the Unity Underlying Them (London: Longmans, Green, \& Co, 1899); Ernst von Bunsen, Die Einheit der Religionen: Im Zusammenhange mit den Völkerwanderungen der Urzeit under der Geheimlehre, I-II (Berlin: Mitscher \& Röstell, 1870). 
the greatest possible political relevance in a time of globalisation and intercontinental conflict, the paucity of attention the fundamental unity of mankind has received in recent decades can only surprise us. ${ }^{41}$

At this point, let us make a transition from empirical-scientific to philosophical (and theological) approaches to our topic. H.C. Baldry brings together what the Ancient Greeks thought on this point. ${ }^{42}$ These did not explicitly have the notion of an all-encompassing humanity (othering in terms of $\beta \alpha \dot{p} \beta \alpha$ por Barbarians was their dominant discourse); yet their common discourse on the distinctions between humans, gods and animals implied an underlying awareness of human unity. So did, for instance, the fact that in order to explain the antecedents of a regional and, at the time, recent phenomenon, the Persian Wars, Herodotus (fifth century вСЕ) saw himself compelled to spin a broad tale encompassing the entire known world with one chapter for every major region - Egypt, Persia, Scythia, etc. ${ }^{43}$ Yet instead of such implied universalism, particularism won the day: the Greeks' victory in the Persian Wars - although for the Persians almost a backwater skirmish - came to be celebrated as constitutive of the unique identity and quality of the (Eurasian) West, the myopic exaltation of the Greek genius against which the Ex Oriente Lux movement (early twentieth century CE) and the Black Athena debate (from the mid-1980s CE on) have battled right into our time and age. The notion of the unity of humanity we only see emerge with the Romans - notably Cicero - under the protoglobalisation conditions of the growing Roman Empire. ${ }^{44}$ However, in this connection we need to keep in mind that, even when an explicit application to humanity cannot be readily attested, a struggle with the more general problem

41 A notable exception has been the pioneer collection by Edgar Morin and Massimo Piatelli-Palmarini (eds, L'unité de l'homme: Invariants biologiques et universaux culturels (Paris: Seuil, 1974), to which some of the greatest minds in that generation of anthropologists have contributed (e.g. Dan Sperber or Luc de Heusch); yet its impact has remained limited.

42 See H.C. Baldry, The Unity of Mankind in Greek Thought (Cambridge: Cambridge University Press, 1965).

43 See Herodotus, Historiën [Greek text of the Historiae], ed. B.A. Van Groningen [Leiden: Brill, 1963 (fifth century вСЕ)].

44 Redaktion, "Menschheit, Menschengeschlecht [I. Antike, Mittelalter, und frühe Neuzeit]," in Joachim Ritter, Karlfried Gruender, and Gottfried Gabriel, eds, Historisches Wörterbuch der Philosophie: Unter Mitwirkung von mehr als 1200 Fachgelehrten: Völlig neugearbeitete Ausgabe des 'Wörterbuchs der philosophischen Begriffe' von Rudolf Eisler, I-XIII (Darmstadt: Wissenschaftliche Buchgesellschaft, 2001), cols v, 1127-1128. 
of unity in diversity has been a constant in Ancient thought, both among the Greeks ${ }^{45}$ and among the Ancient Egyptians. ${ }^{46}$

Through the centuries, Jewish and Christian theologians and Biblical scholars have often been inspired by the suggestion of fundamental unity of all of humankind as emerging from the Biblical account(s) of the Flood concerning the one surviving family. ${ }^{47}$ This implication almost extends to a global scale,

45 See ibid., Erich Heintel, “Eine (das), Einheit," cols II (2001), 361-384; Michael C. Stokes, One and Many in Presocratic Philosophy (Washington DC: Harvard University Press for Center for Hellenic Studies. Stokes 1971); Arthur W.H. Adkins, From the Many to the One: A Study of Personality and Views of Human Nature in the Context of Ancient Greek Society, Values, and Beliefs (London: Constable, 1970). See also Empedocles's four-element system, the much more general cyclical cosmology of element transformation, may be regarded as a solution to this problem, in Wim M.J. van Binsbergen, Before the Presocratics: Cyclicity, Transformation, and Element Cosmology: The Case of Transcontinental Pre- or Protohistoric Cosmological Substrates Linking Africa, Eurasia and North America, special issue, Quest: An African Journal of Philosophy / Revue Africaine de Philosophie, XxIII-XXIV, 1-2 (20092010): 1-398. Book version in Haarlem: Shikanda, 2012; full text at: http://www.quest -journal.net/2009-2010.htm. And in the same light may be viewed as the idea underlying alchemy, in Carl Gustav Jung, "Die Symbolik der Polarität und Einheit (Kapitel IV-VI)," in Mysterium coniunctionis: Untersuchungen über die Trennung und Zusammensetzung der seelischen Gegensätze in der Alchemie, Psychologische Abhandlungen, II (Zürich: Rascher, 1956).

46 See Erik Hornung, Der Eine und die Vielen: Ägyptische Gottesvorstellungen (Darmstadt: Wissenschaftliche Buchgesellschaft, 1971); English translation by John Baines, Conceptions of God in Ancient Egypt: The One and the Many (London: Routledge \& Kegan Paul, 1983). See also an interesting parallel among the Zulu of Southern Africa, by Lizo Doda Jafta, perhaps consciously intended / imposed by the latter author (see Jafta's "The One, the Other, the Divine, the Many in Zulu Traditional Religion of Southern Africa," Dialogue and Alliance 6 (1992): 79-9o). In recent decades, an Afrocentrist-inspired Egyptocentrism has become, once more, a dominant interpretative model among African intellectual and religious elites. Once more, Martin Gardiner Bernal claims that such an ancient model was also standard in the West from Antiquity to the seventeenth century CE. See Martin Gardiner Bernal, Black Athena: The Afroasiatic Roots of Classical Civilization, I. The Fabrication of Ancient Greece 1787-1987; II. The Archaeological and Documentary Evidence; III. The Linguistic Evidence (London: Free Association Books / New Brunswick: Rutgers University Press, 1987).

47 See Genesis 7-10; Bernhard W. Anderson, "The Babel Story: Paradigm of Human Unity and Diversity," in Andrew Greeley, ed., Ethnicity (New York: Seabury, 1977), 63-70; Norman C. Habel, "The Two Flood Stories of Genesis," in Alan Dundes, ed., The Flood Myth (Berkeley \& London: University of California Press, 1988), 13-29; Allen P. Ross, "The Dispersion of the Nations in Genesis 11:1-9," Bibliotheca Sacra 138 (1981): 119-138; Wim M.J. van Binsbergen, and Fred C. Woudhuizen, "Ethnicity in Mediterranean Protohistory," British Archaeological Reports (BAR) International Series No. 2256 (Oxford: Archaeopress, 2011), ch. 6; also at: http://www.quest-journal.net/shikanda/topicalities/ Ethnicity_MeditProto_ENDVERSION\%2odef\%2oLOW\%2oDPI.pdf. 
population

language group

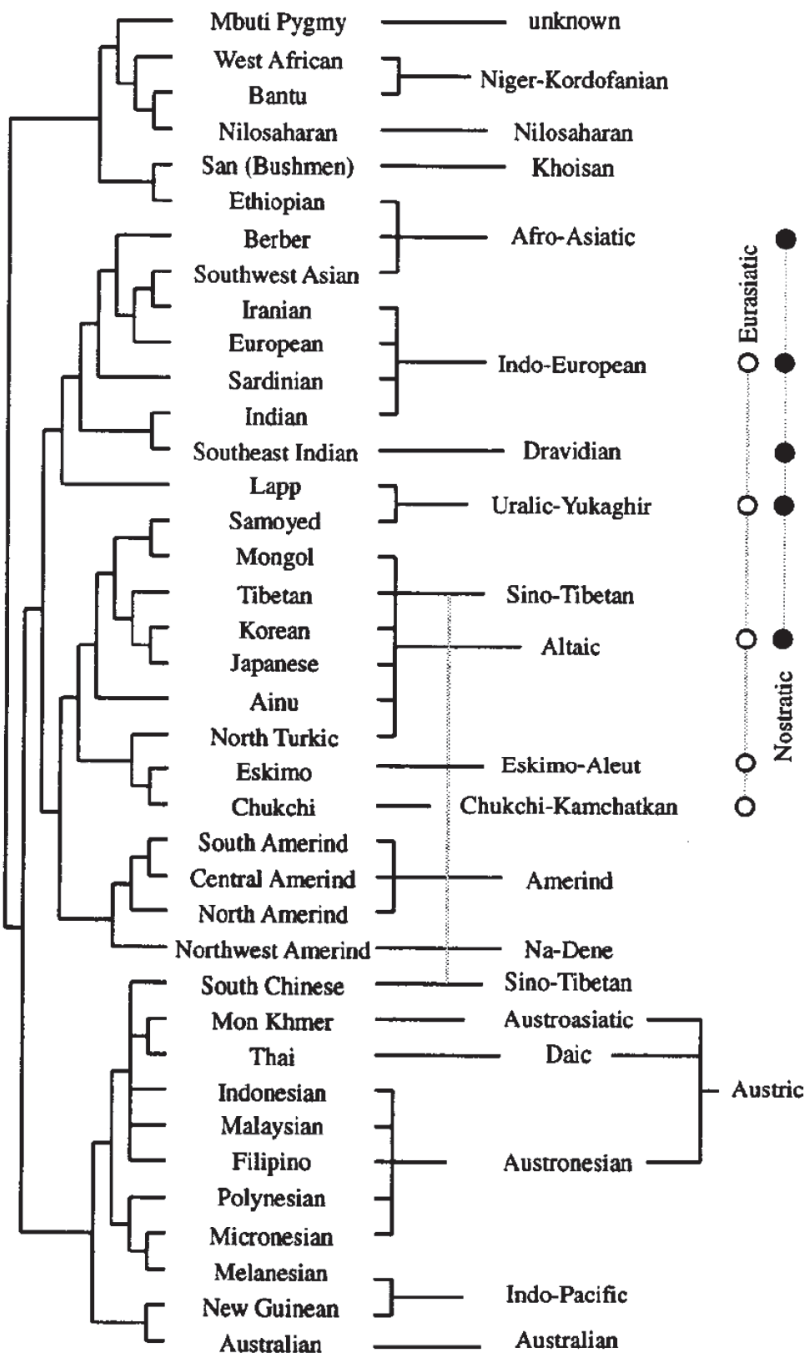

FIGURE 1 All but excluding Africans from the unity of humankind: the othering of Africans disguised as inescapable scientific truth: African genes and languages are places in one dendrogram branch on its own, while the rest of humankind is claimed to cluster massively together. Note: This is a much-cited diagram from Luigi Luca Cavalli-Sforza, "Genes, People, and Languages," Proceedings of the National Academy of Sciences of the United States of America 94 (1997): 7722. 
since flood myths are among the few mythical near-universals of Anatomically Modern Humans. ${ }^{48}$

In philosophy the idea of humanity and the theoretical and conceptual elaboration of its unity has received extensive attention. ${ }^{49}$ With St Paul, and again prompted by the mounting proto-globalisation in the Roman Empire in the first century CE, Christianity took a radical distance from the parochialism of Judaism where the unique Supreme God had been largely particular to the Israelites; instead, St Paul formulated and propagated the idea that all of humankind is in principle sharing in the same salvation history. In the world of Islam the emerging idea of one humanity was to some extent mirrored, like so much else in Judaism and Christianity, by the concept of al-Umma, "the community of all believers"; however, not thus transmitted into Islam was St Paul's most seminal idea: that this community also comprised the non-believers, effectively the whole of humankind, and not just by first principles through a logical operation, but more dynamically through a universally shared history of salvation. Hence Islam tends to lack both a sense of a collective, secular history of accumulative, qualitative change (Islam's sense of history seems to be limited to eschatology, which today the terrorist movement of the Islamic State is enacting with human decapitation, mass slaughter, destruction of ancient monuments, and sacred battle-fields named in the al-Hadith traditions from the Prophet Muhammad's time), and also lacks a sense of the non-theocratic dimension of human society.

The Paulinian idea did inspire Western philosophy with the idea of the fundamental unity of humankind, which after a chequered trajectory in Late

48 See Mark Isaak, who offers a nicely referenced overview of many hundreds of flood myths, half of which happen to be from North America ("Flood Stories from Around the World," at http://home.earthlink.net/ misaak/floods.htm, accessed 24 August 2011); Wim M.J. van Binsbergen, with the collaboration of Mark Isaak, "Transcontinental Mythological Patterns in Prehistory: A Multivariate Contents Analysis of Flood Myths Worldwide Challenges Oppenheimer's Claim that the Core Mythologies of the Ancient Near East and the Bible Originate from Early Holocene South East Asia," Cosmos: The Journal of the Traditional Cosmology Society 23 (2007): 29-80, full text at: http://www .quest-journal.net/shikanda/ancient_models/Binsbergen_Edinburgh_2007_\%2ofor_ Cosmos.pdf; Michael Witzel, "Pan-Gaean Flood Myths: Gondwana Myths - and Beyond," in Wim M.J. Binsbergen and Eric Venbrux, eds, New Perspectives on Myth: Proceedings of the Second Annual Conference of the International Association for Comparative Mythology, Ravenstein (the Netherlands), 19-21 August, 2008, Papers in Intercultural Philosophy and Transcontinental Comparative Studies (Leiden / Haarlem: Shikanda, 2010), 217-235; and extensive sources cited there.

49 See Redaktion, "Menschheit, Menschengeschlecht [I. Antike, Mittelalter, und frühe Neuzeit]"; and H.E. Bödeker ("Menschheit, Menschengeschlecht [II.]", cols v, 1129-1137) to whom the following paragraph is much indebted. 
Antiquity, the Middle Ages and Early Modern times, was elaborated especially from Johann Gottfried Herder on ${ }^{50}$ with emphasis on Man as a historic subject. Immanuel Kant largely situates that unity in the shared Vernunft / Reason and in the human community that the aesthetic judgment creates by implication, ${ }^{51}$ although it also plays a pivotal role in Kant's pre-critical pioneering of cultural and physical anthropology. ${ }^{52}$ Also in general, in Western philosophy during the Enlightenment and Romanticism, the emphasis was more on the rational and aesthetic potential of the human condition than on the awareness of its cultural and somatic diversity - even though the populations of the South still remained largely outside the scope of Western philosophy during that period. In Hegel, the unity of humankind is gradually borne out by the universal Geist / Spirit, with emphasis on historical rather than spatial unity, and ominously, explicitly, leaving room for the possibility that certain sections of humankind, e.g. Africans, do not participate in that unity. Foreshadowing Émile Durkheim's theory of religion as society's veneration of itself, ${ }^{53}$ Auguste Comte's positivist project proposed a "religion de l'humanité" implying the latter's fundamental unity. ${ }^{54} \mathrm{~A}$ philosophical view on world complexity in unity is found in the thought of Karl Marx and Friedrich Engels, ${ }^{55}$ with the implication that not the myriad dimensions of somatic or cultural difference but only the handful of distinct class positions have mattered in history, and with ultimately the utopian possibility of a future dissolution of all divisive class differences and

50 See Johann Gottfried, Sämmtliche Werke, eds. B. Suphan, J. Balde, C.C. Redlich, and R. Steig (Berlin: Weidmannsche Buchhandlung, 1913 [1877]).

$5^{1}$ See Immanuel Kant, Kritik der reinen Vernunft, Vols. III \& IV of: Kant, I., Werke in zehn Bänden, W. Weischedel, ed., Sonderausgabe (Darmstadt: Wissenschaftliche Buchgesellschaft, 1983 [1781]) and "Kritik der Urteilskraft," in W. Weischedel, ed., Kritik der Urteilskraft und Schriften zur Naturphilosophie, in: Kant: Werke in Zehn Bänden, VIII, Sonderausgabe (Darmstadt: Wissenschaftliche Buchgesellschaft, 1983 [1787]), 233-620; see Christine Korsgaard, "Kant's formula of humanity," Kant-Studien 772 (1986): 183-202. For, in Kant's view (1983b), when I call a thing beautiful, I imply that it should be beautiful to all people. For a critical African application of this idea, see my own contribution to Kimmerle \& Oosterling 200o, barely tolerated, and graded down, by the editors to "a social-science comment," in Heinz Kimmerle and Henk A.F. Oosterling, eds, Sensus Communis in Multi- and Intercultural Perspective: On the Possibility of Common Judgments in Arts and Politics (Würzburg: Königshausen \& Neumann, 2000).

52 See David G. Sussman, The Idea of Humanity: Anthropology and Anthroponomy in Kant's Ethics (New York \& London: Routledge, 2001).

53 Émile Durkheim, Les formes élémentaires de la vie religieuse: Le système totémique en Australie (Paris: Presses Universitaires de France, 1960 [1912]). 1912 / 1960); see van Binsbergen, Confronting the Sacred.

54 See Auguste Comte, Cours de Philosophie Positive, I-III (Paris: Bachelier, 1830-1842).

55 See Karl Marx and Friedrich Engels, Karl Marx - Friedrich Engels, Gesamtausgabe (MEGA) (Berlin: Dietz, 1975-1983). 
contradictions. This continuingly inspiring view of human unity was almost diametrically opposed to Friedrich Nietzsche's subordinating and implacable emphasis on the internal segmentation of humanity in an elect minority of Supermen versus a despicable majority. ${ }^{56}$ From the mid-nineteenth century CE on, the unity of humankind is perceived, by Neo-Kantianism, in a religious or ethical sense. ${ }^{57}$ In Max Scheler it takes a planetary dimension. ${ }^{58}$ The perception of a common humanity ${ }^{59}$ is often argued to be at the heart of empathy,

${ }_{5} 6$ See Friedrich W. Nietzsche, "Also sprach Zarathustra (1885)," in Werke, ed. Karl Schlechta, Karl (München / Wien: Hanser, 1973 [1885]), II, 275-561.

57 Hermann Cohen, Ethik des reinen Willens (Berlin: Cassirer, 1904).

$5^{8}$ Max Scheler, Vom ewigen im Menschen: Die christliche Liebesidee und die gegenwärtige Welt, in Max Scheler Gesammelte Werke, ed. Maria Scheler (Bern: Francke, 1954 [1917]), v, $355-401$.

59 In this connection, I might have pointed to African philosophies of "humanity" under such headings as muntu and ubuntu [see Frans Placied Tempels, Bantoe-filosofie (Antwerpen: De Sikkel, 1955); Janheinz Jahn, Moentoe: Contouren van de neo-Afrikaanse cultuur (Amsterdam: Moussault, 1967 [1958]); Fabien Eboussi-Boulaga, La crise du muntu: Authenticité africaine et philosophie (Paris: Présence Africaine, 1977); Mogobe B. Ramose, African Philosophy through Ubuntu (Avondele: Mond, 1999)]; but usually their referent can be demonstrated to be not so much universal humanity through space and time, but Black people in Africa under circumstances of colonial oppression. In other words, a usage predicated on Whites's misuse of the word Bantu as directly or indirectly tributary to, or secondarily assimilated to, colonial practice, and therefore no longer sharing in the universalism which "humanity" as a philosophical term implies. This is also how the term botho / ubuntu was spontaneously understood by our informants during exploratory interviews that Mogobe Ramose, Vernie February and I conducted in South Africa in early 1999. See Wim M.J. van Binsbergen, "Ubuntu and the Globalisation of Southern African Thought and Society," in African Renaissance and Ubuntu Philosophy, ed. Pieter Boele van Hensbroek, special issue of Quest: An African Journal of Philosophy 15, 1-2 (2001): 5389, also at: http://shikanda.net/intercultural_encounters/index.htm; revised reprint in Wim M.J. van Binsbergen, Intercultural Encounters: African, Anthropological and Historical Lessons towards a Philosophy of Interculturality (Berlin, Hamburg \& London: LIT, 2003), 427-458, also at http://shikanda.net/intercultural_encounters/Intercultural_encounters_ FINALDEFDEF9.pdf

An interesting argument was developed in the work of an African cleric who for Valentin Mudimbe has been one of the heroes of what the latter has called "clerical intellectualism" in the African context, and which Mudimbe sees as one of the most important spiritual mutations taking place on the African continent in the course of the twentieth century CE. (See Wim M.J. van Binsbergen, “'An Incomprehensible Miracle' Central African Clerical Intellectualism versus African Historic Religion: A Close Reading of Valentin Mudimbe's Tales of Faith," in Reading Mudimbe, ed. Kai Kresse, special issue of Journal of African Cultural Studies 17, 1 (June 2005): 11-65; also at: http://www.quest-journal .net/shikanda/publications/ASC-1239806-193.pdf). I am referring to Vincent Mulago, whose 1962 dissertation (published in 1965 by Présence Africaine) contrasts two forms of "vital unity": that of "Bantu culture" and that of the Roman Catholic Church. But again, one suspects that Mulago's referent is primarily the muntu, not of several millennia of 
altruism, reconciliation, and interculturality. ${ }^{60}$ The question of the fundamental unity of humankind continues to inspire philosophical investigation. ${ }^{61}$ It is however ignored in Oswald Spengler's tragic vision of world history. ${ }^{62}$ Later

Bantu-speaking culture, but of colonial condescension and oppression. (The struggle to have the word muntu ("fellow-human," and a fortiori "fellow-Black") unreservedly applied to myself, and to be allowed to share in the common social practices of respect implied in that term (e.g. not being seated on a chair in the presence of a king, not dining with one, but on the affirmative side being recognised to have a clan / totem, and being allowed to share in the ribald joking between specific clans) has constituted one of the main strands in my participant observation among the Nkoya people - Western Zambia, South Central Africa - over nearly five decades.) In other words, in the course of the twentieth century CE the use of the Bantu root -ntu, "human," was contaminated to the point of perversion by its appropriation by racialist and colonial political systems of oppression. This root was perhaps originally borrowed from the linguistic phylum called Austronesian (today only found in South East Asia, Oceania and Madagascar), yet it belongs to the world-wide "Earth / bottom / human" complex - one of the few truly global etymologies scholarship has identified (see Wim M.J. van Binsbergen, Confronting the Sacred:Durkheim Vindicated through Philosophical Analysis, Ethnography, Archaeology, Long-range Linguistics, and Comparative Mythology (Hoofddorp: Shikanda Press, 2018), Appendix IV, $535 f$; also at: http://www.quest-journal.net/shikanda/topicalities/naar\%2owebsite\%208-2018/Table_ of_contents.htm). Within a long-range regional, African horizon, this root can be considered to define the category of all humans as distinguished from the rest of the visible world - thus in the standard Nkoya expression Nyambi balengile bitondo na bantu, "Nyambi [the High God] created the trees [by implication: all non-human things] and humans" cf. Genesis 1:1f - where the creation consists in the first place, not just of Trees and Man (although those too, emphatically), but of Heaven and Earth. In the Nkoya worldview, Nyambi appears especially as an awesome mythical presence in the deep forest where only specialist hunters penetrate. Also among the Lele of Kasai, Congo Democratic Republic, Nyambi has this close association with the forest. See Mary Douglas, The Lele of the Kasai (London: Oxford University Press for International African Institute, 1963); Arthur Cotterell, The Illustrated Encyclopedia of Myths and Legends (London: Guild, 1989), 228. On the extensive modern influence of the Bible on Nkoya conceptualisations, see Wim M.J. van Binsbergen, Tears of Rain: Ethnicity and History in Central Western Zambia (London \& Boston: Kegan Paul International, 1992), ch. 3; also at http://www.shikanda .net/ethnicity/Tearsweb/pdftears.htm.

6o See Kirsten Renwick Monroe, The Heart of Altruism: Perceptions of a Common Humanity (Princeton: Princeton University Press, 1996).

61 E.g. Bernard Williams, Bernard, Making Sense of Humanity and Other Philosophical Papers, 1982-1993 (Cambridge: Cambridge University Press, 1995); Alain Badiou, Badiou, Théorie du sujet (Paris: Seuil, 1982) and St Paul: The Foundations of Universalism, trans. Ray Brassier (Stanford CA: Stanford University Press, 2003), see Paul Ashton, A.J. Bartlett and Justin Clemens, eds., The Praxis of Alain Badiou (Melbourne: re.press [sic], 2006).

62 See Oswald Spengler, Der Untergang des Abendlandes: Umrisse einer Morphologie der Weltgeschichte, I-II [München: D[eutsche]T[aschenbuch]V[erlag], 1918-1922] (München: Beck, 1993). 
conceptual developments in the course of the twentieth century CE kept pace with the growth of globalisation, of international social, economic and political organisation, and of inter-statal conflict. Here the Indian / German intercultural philosopher Ram Adhar Mall stands out as a particularly sensitive and broadly orientated guide; ${ }^{63}$ while the Nigerian philosopher Eze (a stern critic of Kant's and Hegel's racism) has explored how the very concept of a common humanity allows us to overcome the subordinating particularism of racism. ${ }^{64}$

So far, I have presented a few highlights on the fundamental unity of humankind as a prerequisite for any intercultural philosophy. However, in current global politics the idea of such unity, however irrefutable, appears to be of little practical value unless we manage to have it implemented by other than philosophical means.

Although the ex-Marxist Samuel Huntington's pessimistic, Spenglerian idea of the Clash of Civilizations is to be faulted on many counts, ${ }^{65}$ what it does convey is the awareness that the present-day violent and massive conflicts between militant Islamists and the North Atlantic region are not so much about scarce resources (including power, mineral oil, and hegemony), but about models of thought that constitute reality in such fundamental, and such fundamentally different, ways that, to the actors involved, they appear to justify murder and dying for. When I started out as an intercultural philosopher in the

63 Ram Adhar Mall, "Hermeneutik und Weltphilosophie: Zur Kritik einer reduktiven Hermeneutik," in Wolfgang Kluxen and Tilman Borsche, eds, Tradition und Innovation, XIII. Deutscher Kongreß fur Philosophie (Bonn, 1984) (non vidi); with specific application to hermeneutics and the unity of humankind: "Unity without Uniformity: Prolegomena to any Theory of Hermeneutics," in Berndine F. Nel, W.M. Venter and Ratnamala Singh, eds, Focus on Quality: Selected Proceedings of a Conference on Qualitative Research Methodology in the Social Sciences (Durban: Institute for Social and Economic Research, University of Durban-Westville, 1985) (non vidi); "Überlegungen zu einer interkulturellen Vernunft," in Erwin Schadel and Uwe Voigt, eds, Sein - Erkennen - Handeln: Festschrift fur Heinrich Beck zum lxv. Geburtstag (Frankfurt am Main: Lang, 1994), 53-59; Ram Adhar Mall and Dieter Lohmar, eds, Philosophische Grundlagen der Interkulturalität (Amsterdam \& Atlanta: Rodopi. 1993); see Wim M.J. van Binsbergen, Intercultural Encounters: African, Anthropological and Historical Lessons towards a Philosophy of Interculturality (Berlin, Hamburg \& London: LIT, 2003), ch. 12, 375-395; also at: http://shikanda.net/intercultural_ encounters/Intercultural_encounters_FINALDEFDEF9.pdf.

64 See Emmanuel Chukwudi Eze, ed., Race and the Enlightenment: A Reader (Oxford: Blackwell., 1997); “The Color of Reason: The Idea of 'Race' in Kant's Anthropology," in Emmanuel Chukwudi Eze, ed., Postcolonial African Philosophy: A Critical Reader (Oxford: Blackwell, 1997), 103-140; Achieving our Humanity: The Idea of the Postracial Future (New York \& London: Routledge, 2001).

65 See Samuel Huntington, The Clash of Civilizations and the Remaking of the World Order (New York: Simon \& Schuster, 1996). 
mid-199os, I was convinced that intercultural philosophy could make a positive contribution to solving this kind of problems of identity and communication in the modern, globalising world. In this spirit I wrote, shortly after " $9 / 11$," a passionate though (intended as) impartial interpretation of that tragic event. ${ }^{66}$ Meanwhile however, the aftermath of " $9 / 11$," both in the Middle East and in the North Atlantic region, has totally robbed me of such confidence and left me disgusted, which has been a factor in my retreat from intercultural philosophy as my major field of intellectual endeavour. While the final editing of my 2015 book was done the IS carnage at the Bataclan Theater, Paris, France, 13 November 2015, took place, three kilometers from my middle daughter's hotel room, and it brought home once more the futility of intercultural philosophy in the face of terrorism. The violence-drunken actions of IS reflect even less a nation's culture than that a Mafia clan's subcultural reliance on violence to regulate economic and political transactions reflects "the culture of Southern Italy." In the hands of IS as an eschatological millenarian movement, the appeal to Islam seems in the first place a pretext to perform the logical operation of separating in-group from out-group, ${ }^{67}$ constituting the in-group through acts of violence, and through that violence committing the out-group to a horrendous fate. To understand the broad mechanisms of the current situation, an appreciation of the technological and logistic vulnerability of modern, urban industrial society is helpful, but between Max Weber's theory of the state's monopoly of violence, ${ }^{68}$ and René Girard's insistence on the constituent nature of violence, our toolkit is fairly adequate, without reserving an unduly large role for intercultural philosophy as a relative newcomer on the intellectual scene. Beyond elucidating how IS's mode of thought puts that movement outside the human order, outside the latter's self-evident appeal to fellowhumanity, I cannot perceive any more how intercultural-philosophical debate

66 See Wim M.J. van Binsbergen, "Towards an Intercultural Hermeneutics of Post-' $9 / 11^{\prime}$ Reconciliation: Comments on Richard Kearney's 'Thinking After Terror: An Interreligious Challenge'," in Journal of Interdisciplinary Crossroads 2, 1 (2005): 60-72, preceded by Richard Kearney's original paper and comments by other scholars, and followed by further comments, Kearney's rejoinder, and a cumulative bibliography covering both Kearney's texts and the various commentaries; full text at: http://www.quest-journal.net/ shikanda/topicalities/oo2\%20Kearney\%2oprintVersion2\%201-2006.pdf; reprinted in van Binsbergen, Vicarious reflections, ch. 5 .

67 See René Girard, Violence and the Sacred, trans. Patrick Gregory (Baltimore: Johns Hopkins University Press, 1977); English translation of La violence et le sacré (Paris: Grasset, 1972).

68 Max Weber, The Theory of Social and Economic Organization, trans. A.M. Henderson and Talcott Parsons (New York \& London: The Free Press / Collier-Macmillan, 1964); English translation of Wirtschaft und Gesellschaft, I (Tübingen: Mohr, 1985 [1919]). 
is to have any impact on this state of affairs. In the best Diltheyan/Weberian tradition, intercultural analysis is predicated on the operation of Verstehen, but how futile is the determination to understand, and to communicate with, a section of humanity that has deliberately and radically defined itself as outside the common human order, and that totally rejects the empathy that a sense of fellow-humanity is supposed to produce? Alternatively, military action might have such an impact - analogous to the morally neutral action of leucocytes eliminating viruses from the living organism.

But perhaps I am simply being too pessimistic. For after all, it was in the first place philosophers (Giordano Bruno, Erasmus, René Descartes, Baruch Spinoza, Kant, Hegel, Marx, Nietzsche, Sigmund Freud, Mahatma Gandhi), rather than natural scientists, technicians or soldiers, who created the framework for modernity and indirectly inspired the mass movements that, within scarcely two centuries, totally changed the socio-political face of the earth in anticipation of the even more profound changes that the most recent technologies of information and communication were to bring about. (As a central feature of its orientation, militant Islam has missed - not to say: rejected this modernist framework. It is available in today's Islam, e.g. in the works of the Iranian philosopher Abdulkarim Soroush, and instead draws its obsolete inspiration from medieval Muslim theologians.) But today's Islamic thought may be a case apart. For the rest, and whether philosophers like it or not, they may yet have a vital prophetic role to play, even in our time and age. Here I take prophetic in the original, Greek sense of "speaking on behalf of ..." (in other words, "vicariously"! $)^{69}$ - on behalf of God, perhaps, in the Israelite and Christian conception, but especially on behalf of contemporary society, whose contradictions the prophet feels as much as anyone else does and manages to express as guidance towards change. ${ }^{70}$ And although I am aware of the futility of the contribution I could make in this respect, it is in this sense that I have realised my considerable recent output of texts and books, passionately and diligently, as if desperately clinging on to seemingly arbitrary precepts of scholarship in the face of apparent barbarism.

69 See van Binsbergen, Vicarious Reflections.

70 See Wim M.J. van Binsbergen, Religious Change in Zambia: Exploratory Studies (London \& Boston: Kegan Paul International, 1981); also at Google Books. 


\section{Biography}

Wim van Binsbergen (1947-) was trained as a sociologist, anthropologist of religion and linguist. For many years he conducted and supervised fieldwork in a variety of African and (more recently) Asian settings. His documentary research has also extended to the Ancient Near East, the Mediterranean, the comparative study of divination systems and mythologies, and Africa's transcontinental continuities. He is emeritus professor of the Foundations of Intercultural Philosophy, Erasmus University Rotterdam, and the Editor of Quest: An African Journal of Philosophy / Revue Africaine de Philosophie. The website http://quest-journal.net/shikanda offers extensive information on his past and current projects and free access to most of his publications, including dozens of books. 